\title{
Assessment of Forest Damage in Croatia Caused by Natural Hazards in 2014
}

\author{
Dijana Vuletić ${ }^{1} \llbracket$, Željko Kauzlarić ${ }^{2}$, Ivan Balenović ${ }^{1}$, \\ Silvija Krajter Ostoić ${ }^{1}$
}

\author{
${ }^{1}$ Croatian Forest Research Institute, Cvjetno naselje 41, HR-10450 Jastrebarsko, Croatia \\ ${ }^{2}$ Croatian forests Ltd., Forest Administratin Delnice, Supilova 32, HR-51300 Delnice, Croatia \\ $\varangle$ Corresponding author: e-mail: dijanav@sumins.hr
}

Citation:

VULETIĆ D, KAUZLARIĆ Ž, BALENOVIĆ I, KRAJTER OSTOIĆ S 2014 Assessment of Forest Damage in Croatia Caused by Natural Hazards in 2014. South-east Eur for 5 (1): 65-79. DOI: http://dx.doi.org/10.15177/seefor.14-07

Received: 26 Apr 2014;

Accepted: 3 Jun 2014;

Published online: 18 Jun 2014

\begin{abstract}
Background and Purpose: Recent natural disasters (ice-breaks, torrents, floods) that affected five Croatian counties caused significant damage on forest stands and forest infrastructure. Since in Croatia there is no common methodology for fast and reliable assessment of forest damage, the aim of this paper is to develop and present methodology for rapid damage assessment and to prescribe urgent recovery measures, as well as to provide first preliminary results of the total damage to forests.
\end{abstract}

Materials and Methods: An attempt was made to develop the methodology which would rely on existing legislations, regulations, instructions and experiences for forest damage assessment as much as possible. Estimation of forest damage was based on field observations, spatial data of forest management units and data from the existing Forest management plans.

Results: According to conducted assessment, forests of Primorsko-goranska County are the most affected by the overall damage caused by ice-storm. Major damages occurred both on the forest and on forest roads. Ice-storm also caused serious damages on forests and on forest roads in Ličkosenjska County and Karlovačka County, while floods and torrents caused damages on forest roads in Zagrebačka County, Sisačko-moslavačka County and Karlovačka County. Money-wise, the total forest damage amounts $942252183 €$.

Conclusions: Methodology for rapid damage assessment presented in this paper resulted on first preliminary estimate of range, intensity and cost of forest damage caused by recent natural disturbances. More precise data on forest damage will be known after the implementation of the proposed emergency recovery measures. Also, certain improvements of methodology in terms of precision and collection of data may be achieved by incorporating remote sensing methods.

Keywords: ice break, torrents, floods, damage assessment methods, forest, natural disaster

\section{INTRODUCTION}

Natural hazards can significantly affect the sustainability of forest ecosystems [1].
Besides the influence on structure and functionality of a forest ecosystem, natural hazards often cause economic loss, especially in managed forests $[2,3]$. Studies on forest 
damage caused by natural disturbances such as ice storms, torrents or floods are infrequent [4], especially in the region of the South-east Europe. However, the negative impact of natural hazards on forests should not be ignored. Schelhaas et al. [5] showed the increasing trend in frequency and severity in the last decades of the major disturbance types in Europe.

In the period between 31 January and 6 February 2014 significant damage of forest ecosystems caused by several natural hazards occurred on the area of five Croatian counties. In the Primorsko-goranska County major forest damage occurred due to freezing rain (icebreaks) in a form of damage of forest stands, forest roads and forest skid-trails. Extreme rain supported by huge water waves from Slovenia resulted in excessive floods, which caused significant damage on forest roads, forest skid-trails and other forest infrastructure in areas of the Zagrebačka County and Sisačkomoslavačka County. Damage in Karlovačka County and Ličko-senjska County was caused by the same stress factors but of lesser intensity. In all affected counties a state of natural disaster was proclaimed. In order to apply to the EU Solidarity Fund, damage assessment had to be done in a very short period.

In Croatia, there is no methodology for fast and reliable assessment of forest damage. Only several studies of earlier date [6-8] dealt with the assessment of forest damage caused by ice-break, mainly after greater damages occurred. Therefore, recent natural disasters raised the need for a methodology that would consolidate existing legislations [9-11], regulations [12-14], instructions and experiences [6-8, 15-19] and propose the use of advanced technology for the assessment of range and intensity of forest damage.

This paper aimed to present the developed common methodology for rapid damage assessment and to prescribe urgent recovery measures, as well as to estimate the total damage of forests in the Republic of Croatia that were caused by natural hazards. Specific measures and procedures applied in this methodology including the procedure for the interpretation of results are shortly described. The cost of damage on forests, forest roads and skid-trails, the cost of recovery, afforestation and protection of newly established stands and the cost of losing forest ecosystem services were calculated, as well as the cost of emergency interventions by Croatian forests Ltd. while enabling public traffic and public access to damaged areas. Furthermore, longterm consequences for forest ecosystems and forestry as economic activity were discussed.

\section{MATERIALS AND METHODS}

\section{Study Area}

The area of five Croatian Counties affected by natural disturbances is shown in Figure 1.

Within each County there is one or more Forest Administrations (FA) which were differently affected by ice-breaks, torrents or floods. FAs are organizational units of Croatian forests Ltd. responsible for the overall (state-owned forests) or partial management (state-owned forests within protected areas - natural parks, privately-owned forests) of forests located within their boundaries. On the area of the counties affected by natural disturbances the following FAs are located: FA Delnice (Primorsko-goranska County), FA Senj (Ličko-senjska County), FA Zagreb (Zagrebačka County), FA Sisak (Sisačko-moslavačka County), FA Karlovac and FA Ogulin (Karlovačka County). Concerning damage on forests caused by ice break the FA Delnice was mainly affected together with National Park Risnjak (Figure 1 - hatched area).

\section{Existing Regulations for Assessment of Forest Damage}

An attempt was made to develop methodology which will rely on the existing regulations for forest damage assessment [9, 10] as much as possible.

The Methodology for Damage Assessment Caused by Natural Disasters [9] prescribes the 


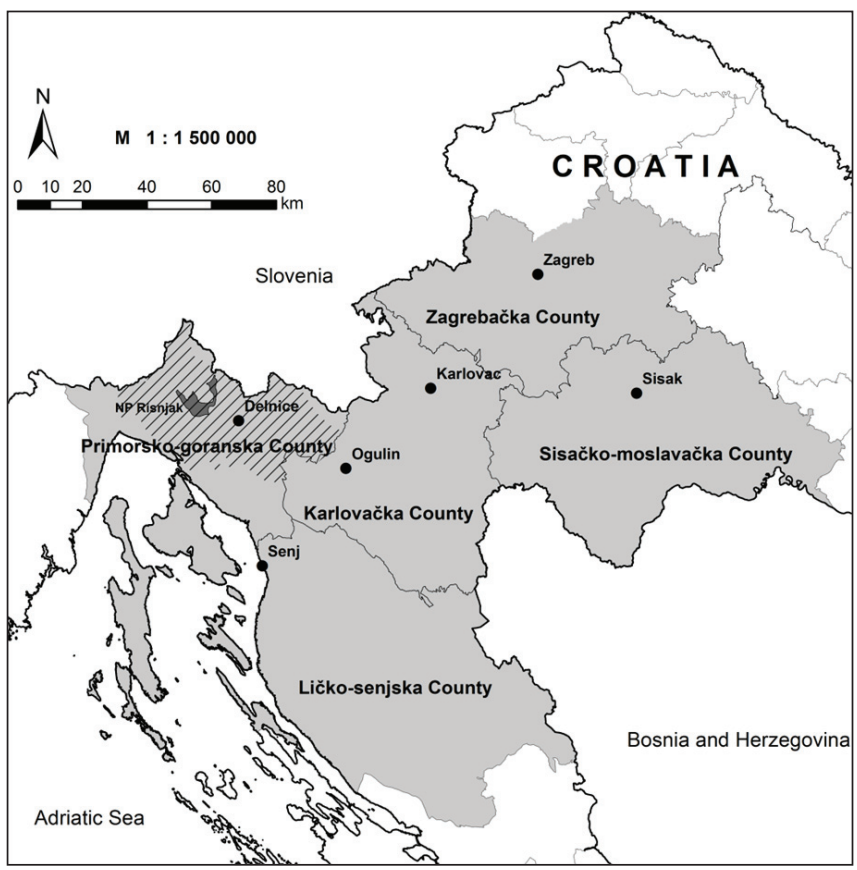

FIGURE 1. The area of 5 Croatian Counties affected by natural hazards including the location of Forest Administrations' (FA) headquarters and National Park (NP) Risnjak. Hatched area in the Primorskogoranska County (NP Risnjak, FA Delnice) presents the most damaged forest area by ice-break.

procedure of damage assessment for damage caused by ice breaks and floods in the Republic of Croatia. The purpose of damage assessment is the assessment of type and scale of damage in units of local government and self-government and the Republic of Croatia in general according to the time and cause of damage, as well as according to the cost of damage for the local population. Calculated costs are expressed in monetary value in terms of the amount needed to repair damaged goods or in some cases to buy new ones. Total damage costs also include costs caused by natural disaster that would not occur otherwise, such as costs of damage risk prevention, work of committees, various refunds etc. According to the Law on Protection from Natural Disasters [10] the refund is allocated only for the mitigation of consequences caused by natural disaster in terms of direct damage on goods, while indirect costs are not taken into account.

\section{Determination of Damaged Area and Damage Intensity}

Usually, the main problem after the occurrence of forest damage is physical access to the affected area. In terms of ice breaks, an initial assessment and emergency interventions could be done during the duration of natural disaster. However, a full assessment is possible only after the ice melts down. During floods limited access is also possible by boat, but also the full assessment is possible only after the water withdraws. Forest damages caused by ice breaks or floods depend on the amount of ice or water and the time of retention in the forest stand.

In case of limited or completely restricted access to forest, remote sensing methods may have advantage over terrestrial methods which will be discussed later in the separate subsection (Incorporation of Remote Sensing Methods). However, due to certain circumstances, such as very short period 
for the delivery of the report on damage assessment which was considerably shorter than the expected delivery time of satellite images, as well as, bad weather conditions (fog, low clouds) for images acquisition, the initial assessment of damaged area and intensity was conducted by using terrestrial methods.

Thanks to precise division on forest compartments, i.e. spatial organization of forests management units in Croatian forests Ltd. and data from relevant Forest management plans the field work and assessment of damages was possible without direct measurements. The work in the field started even during ice-break by cleaning the area from fallen trees and other obstacles to make access to endangered area which enabled marking of damages and assessment of affected area and intensity of damage in the same time.

Forest area affected by the natural disturbances was delineated based on spatial division of forests at least on the compartment level when access was possible. Besides the overall affected area which was determined for orientation purposes and for assessment of loss on forest ecosystem services values, the estimate of damage intensity at the stand (compartment) level was conducted.

The damage intensity of forest stands was assessed in accordance with the Methodology for Damage Assessment Caused by Natural Disasters [9]. For each damaged stand (compartment), a degree of the damage $(P)$ was estimated by evaluating the share of damaged trees in the stand. The value of $P$ was determined by a committee after a visit to the damaged area and its value ranged between 0 and 1.0 with precision of 0.1 . The tree was considered damaged when its upper third of the crown, considered as the most active part of the crown on which depends the possibility of survival of the whole tree, was damaged more than $50 \%$. If the vital part of the crown was damaged less than $50 \%$, the tree was not recorded as damaged. The broken, uprooted trees (Figure 2), and trees with majority of the crown broken were considered as totally damaged (destroyed) trees.

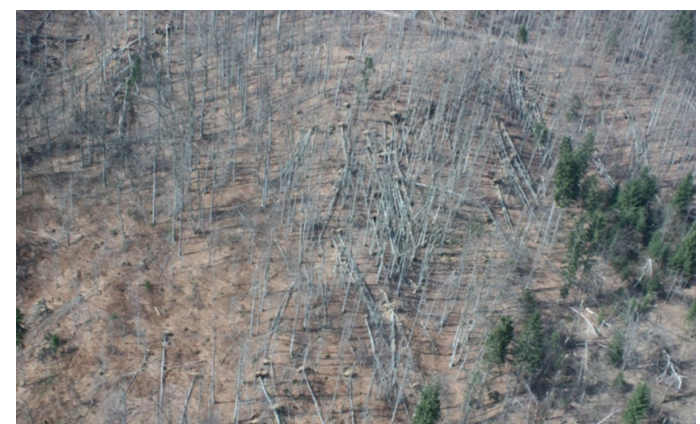

FIGURE 2. Uprooted and fallen trees

According to the estimated degree of damage $(P)$, forest stands were classified into two groups:

1. Damaged forest stands - stands in which share of damaged trees is lower than $70 \%(P<0.7)$. Stands in which the timber is damaged in a way that its economic value is reduced, that the costs of felling, bucking and extraction are enlarged, yet certain potential for utilization of logged timber remains comprised.

2. Destroyed (totally damaged) forest stands - stands in which the share of damaged trees is higher than $70 \%(P>0.7)$. Stands that require recovery. The assumption is that timber from these areas will be logged and extracted without any expectation of its further use except for firewood (woodchip) (Figure 3).

The spatial extent of damage due to floods was initially approximated according to the flooded area, which was hardly accessible or inaccessible. After water withdrawal a more precise data were identified on the damages made by floods or torrents which appeared due to water arrival or withdrawal. In this case the damages were recorded only on infrastructure i.e. on forest skid-trails, classified and unclassified forest roads, due to torrents. This resulted either in the deposition of larger quantities of material on forest roads which made them hardly accessible or inaccessible, or in removal of part of the forest roads and the construction material which led to their damaging. 


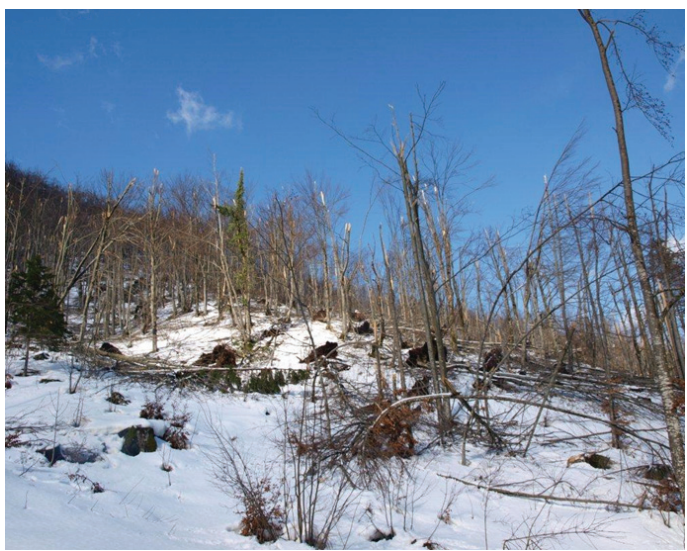

FIGURE 3. Completely destroyed forest stand

In such a way the determined damaged areas served as a basis for further calculation of damage costs, as well as for defining the priority of forest areas for recovery.

\section{Estimate of the total amount of damage Estimate of the total amount of damage (loss of value) on timber volume}

When estimating the damage of natural disasters in the forests, the areas under deciduous and coniferous forests per ha are identified, and then the volume of timber in $\mathrm{m}^{3}$ per timber assortments (damaged or destroyed) in forest stands is estimated [9].

The loss of value of timber volume was obtained as a difference between the values of forest stands before and after the damage occurred. The value of forest stands before the damage occurred was estimated depending on the age and stage of development of the stands in accordance with Regulations on forest management (Chapter VIII, Determination of fees for transferred and limited rights to forest and forest land) [12].

The value of timber assortments (technical and fuel wood) for damaged forest stands was calculated according to the average prices achieved in the previous year (source: Croatian forests Ltd.). The amount of damage was calculated using the form EN-5A ("The damage from natural disasters in the damaged forests") so that the total value of undamaged timber (before natural disturbances) multiplied by the degree of the damage $(\mathrm{P})$.

For totally destroyed forests the value of damage was calculated using the form EN-5B ("The damage from natural disasters in the destroyed forests"). The damage is equal to the total value of damaged forest by assortments (technical and fuel wood) reduced in accordance with the percentage of the use of timber.

In order to calculate the total damage of timber, increased costs of harvesting of destroyed trees as well as loss of timber increment were added to the loss of value of timber volume. Increased costs of harvesting, i.e. costs of felling, bucking and extraction of destroyed trees to the roadside were calculated based on the determined priority forest areas for recovery. Priority forest areas for recovery by felling are determined as the quarter of the totally damaged area prescribed for urgent recovery by felling, bucking and extraction of all the trees regardless of whether they are broken or uprooted. Increased costs of harvesting were calculated by multiplying destroyed timber volume with the average cost of harvesting of $16 € / \mathrm{m}^{3}$ (source: Croatian forests Ltd.). For the calculation of loss of timber increment, the average increment of the affected area of $5.9 \mathrm{~m}^{3} / \mathrm{ha}$ was used [20]. This was multiplied with the total destroyed area, so an overall increment value on this area was multiplied with the average value of $41 € / \mathrm{m}^{3}$ and multiplied with 30 i.e. the number of years in which we expect that new stands will reach its stability and ability to fulfil all its functions after recovery.

\section{Costs of recovery (sowing or planting of seedlings)}

Due to the risk of erosion on the identified priority areas for recovery, sowing or planting of seedlings need to be done in a certain timeframe which means in the same vegetation period or, at the latest, at the beginning of the next growing season [11].

Areas scheduled for the recovery by replanting were determined in the same proportion for both state and private forests, 
and the costs of recovery were planned in the same amount according to the valid scale of charges and in accordance with existing standards, using the workforce of the Croatian forests Ltd and their external services.

The following activities were included in the calculation costs of: (a) soil preparation, (b) planting of new young stands with an estimate of the required planting material, (c) tending and protection of new young stand, and (d) additional revision of Forest management plans (Table 4). Required working days and quantities of planting material were taken from the existing norms of Croatian forests Ltd.

\section{Determination of damages on forest roads and forest skid-trails}

The damages on forest roads and forest skid-trails were classified as follows:

1. Damages on forest roads were classified in two groups:

a. Damages occurred as a consequence of down timber and breakage of trees fallen on the roads causing direct damage i.e. the roads are closed for traffic which requires clearing of roads in order to prepare conditions for free access and recovery of the affected areas.

b. Damages occurred on roads themselves which are visible as landslides, damaged system of longi-tudinal and transversal drainage and damages on the road cross-section, its upper and lower stratum/layer, affected after the ice melt or water withdrawal (Figure 4, left).

2. Damages on forest skid-trails which encompass damages which occurred as a consequence of down timber and breakages, and the impact of water, require recovery in order to allow free traffic communication and access to the affected areas for the purposes of recovery (Figure 4, right).

3. Construction of new skid-trails in order to allow the access to the forest areas which were severely damaged by natural disturbances, in order to conduct further necessary measures of recovery.

In order to ensure functionality of the local population in the affected areas emergency measures in terms of establishment of public traffic on important roads and public access to facilities were undertaken by Croatian forests Ltd. Therefore, the costs of the undertaken emergency measures were also estimated.

\section{Costs of damage (loss of value) of forests ecosystem services (FES)}

Besides the marked-validated forest products (timber products, non-wood products), forests

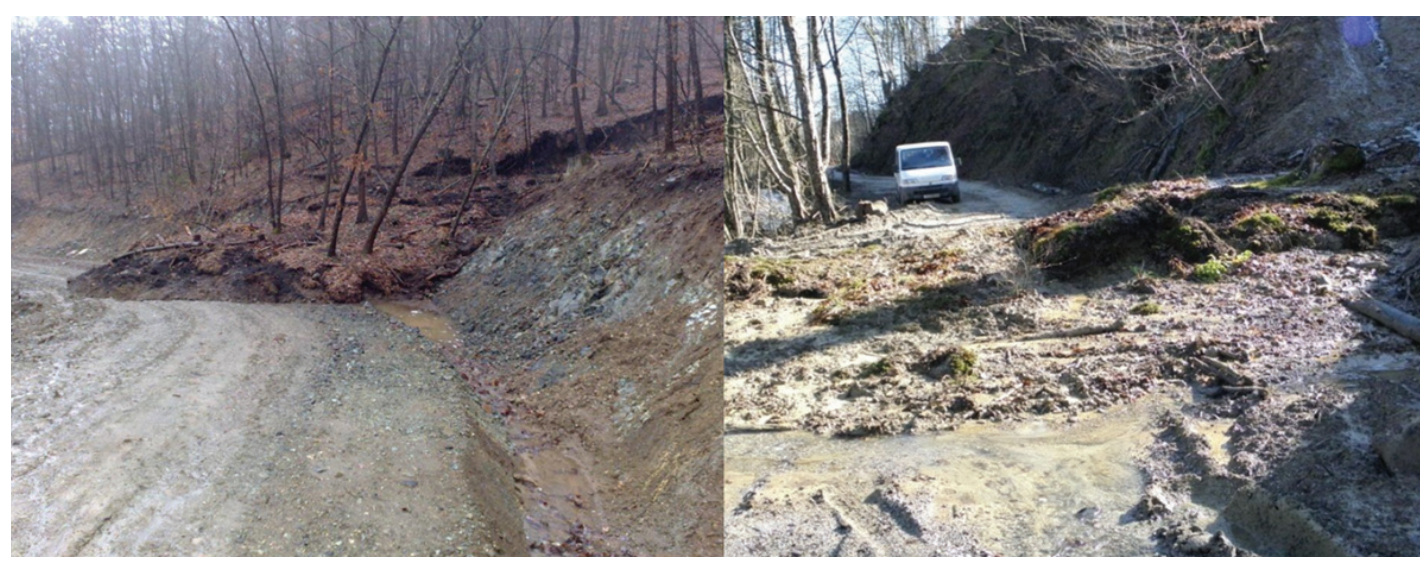

FIGURE 4. Left: Damages on forest road caused by landslide. Right: Damages on forest skid-trail 
provide both material (e.g. tourism, hunting, etc.) and intangible (e.g. positive impact on forest health) benefits, known as forest ecosystem services (FES), in which people can enjoy [21-23].

The value of forests ecosystem services (FES) is defined by the Law on Forests [11], Regulations on forest management [12], Regulations on the method of accounting, forms and deadlines for payment of fees for the forests ecosystem services (FES) [13] and Regulation on the fee transferred and limited rights on forest and forest land [14].

Although natural disasters are not listed among the reasons for which the fee is calculated, alogic of Regulation [14] was applied in the estimate of the total damage to the forests to which the loss of FES will be added. According to the Regulations on forest management [12], for each forest on the compartment level the value of FES was estimated according to: protection of soil, roads and other structures from erosion, torrents and floods, the impact on the water regime of the hydroelectric system, the impact on soil fertility and agricultural production, the impact on the climate, protection and improvement of the environment, creating oxygen and purifying the atmosphere, recreational, tourist and health functions, and the impact on fauna and wildlife.

Estimate of the loss of FES was done in accordance with the estimated degrees of damage and the contribution of the damage on the level of management unit using the average value identified in the forms 0-16 of the valid Forest management plans. In accordance with the prevailing intensity of damage the FES value was reduced by $40 \%$ (average estimated reduction in the value of forests for all stands is $40 \%$ ), for less damaged stands the value was reduced by $20 \%$ while for destroyed stands the total value of FES was calculated as damage.

\section{Calculation of the total damage of forests}

Calculation of the total damage of forests and forest infrastructure caused by recent natural disasters was done by summarizing the estimated costs of all damages. Furthermore, the calculation of the cost of conducted emergency measures from the side of Croatian forests Ltd. professionals during the assistance for the establishment of public traffic on important roads and public access to facilities was done.

\section{RESULTS}

\section{Forest area affected by natural hazards}

In total, 56021.68 ha of forests were affected by damages all in the Primorskogoranska County (FA Delnice), Karlovačka County (FA Ogulin) and the Ličko-senjska County (FA Senj). Based on the degree of damage (P) estimated on compartment (stand) level, it was found that 19245.79 ha of forests have been seriously damaged, while 9808.22 ha of forests have been totally destroyed (Table 1).

Degrees of damage are shown on maps of damaged (Supplementary material 1, Supplementary material 2) and destroyed (Supplementary material 3, Supplementary material 4) forests for broadleaved and coniferous species separately. These maps illustrate the seriousness of the damage and define the priority of forest areas for recovery (sanation). They are also good indicators of spatial distribution of this disaster and its various degrees of damage.

TABLE 1. Forest area affected by natural hazards (FA Delnice, FA Senj, FA Ogulin)

\begin{tabular}{cccc}
\hline Ownership & $\begin{array}{c}\text { Overall affected area } \\
\text { (ha) }\end{array}$ & $\begin{array}{c}\text { Damaged forest stands } \\
\text { (ha) }\end{array}$ & $\begin{array}{c}\text { Destroyed forest stands } \\
\text { (ha) }\end{array}$ \\
\hline State-owned & 45821.90 & 9522.36 & 7377.36 \\
Privately-owned & 10199.78 & 9723.43 & 2430.86 \\
\hline Total & 56021.68 & 19245.79 & 9808.22 \\
\hline
\end{tabular}




\section{Total amount of damage}

Damage on timber volume (loss of value)

The loss of timber volume of damaged and destroyed stands for FA Delnice, FA Senj and FA Ogulin was calculated according to the described methodology, i.e. by subtracting the value of damaged or destroyed forest stands from the value of forest stands before the damage.

The loss of values of damaged and destroyed forests was calculated as the sum of the loss of reduced values of damaged timber (Table 2. 1A) and the loss of the value of destroyed timber (Table 2. 1B) and it amounted to $67528498 €$.
The loss of the value of destroyed timber (Table 2. 1B) was calculated as a difference between the destroyed and damaged timber, which is then multiplied by a reduced value of $10 € / \mathrm{m}^{3}$.

Based on the determined priority forest areas that need urgent recovery by felling, bucking and extraction (9 600.59 ha), increased costs of harvesting were calculated. Destroyed timber volume (1 $\left.644946 \mathrm{~m}^{3}\right)$ from the priority forest areas was multiplied with an average harvesting cost of $16 € / \mathrm{m}^{3}$ which resulted with increased harvesting costs of $26259016 €$.

TABLE 2. Loss of values of damaged and destroyed forests (FA Delnice, FA Senj, FA Ogulin)

\begin{tabular}{|c|c|c|c|c|}
\hline \multirow[t]{2}{*}{ Ownership } & \multirow{2}{*}{$\begin{array}{c}\text { Area } \\
\text { (ha) }\end{array}$} & Technical wood & Fuel wood & Total \\
\hline & & \multicolumn{3}{|c|}{$\begin{array}{l}\text { Damaged wood volume } \\
\qquad\left(\mathrm{m}^{3}\right)\end{array}$} \\
\hline State-owned & 45821.90 & 2170686 & 1241299 & 3411985 \\
\hline Privately-owned & 10199.78 & 325471 & 535026 & 860497 \\
\hline \multirow[t]{2}{*}{ Total } & 56021.68 & 2496157 & 1776325 & 4272482 \\
\hline & $\begin{array}{l}\text { Area } \\
\text { (ha) }\end{array}$ & \multicolumn{3}{|c|}{$\begin{array}{l}\text { Destroyed wood volume } \\
\qquad\left(\mathrm{m}^{3}\right)\end{array}$} \\
\hline State-owned & 7169.74 & 743615 & 419522 & 1163137 \\
\hline Privately-owned & 2430.86 & 180956 & 300853 & 481809 \\
\hline \multirow[t]{2}{*}{ Total } & 9600.59 & 924570 & 720376 & 1644946 \\
\hline & & \multicolumn{3}{|c|}{$\begin{array}{l}\text { Wood volume with reduce value } \\
\qquad\left(\mathrm{m}^{3}\right)\end{array}$} \\
\hline State-owned & & 1427589 & 822464 & 2250053 \\
\hline Privately-owned & & 144515 & 234173 & 378688 \\
\hline Total & & 1572104 & 1056637 & 2628741 \\
\hline \multicolumn{2}{|l|}{ Total loss $(€)$} & & & 26287409 \\
\hline \multicolumn{5}{|c|}{ 1B. Loss of value of destroyed wood volume } \\
\hline \multirow[t]{2}{*}{ Ownership } & \multirow{2}{*}{$\begin{array}{c}\text { Area } \\
\text { (ha) }\end{array}$} & \multicolumn{3}{|c|}{ Destroyed (technical and fuel) wood volume } \\
\hline & & & & $(€)$ \\
\hline State-owned & 2160.26 & 116 & & 31923551 \\
\hline Privately-owned & 9723.43 & & & 9317539 \\
\hline Total & 11883.69 & 164 & & 41241089 \\
\hline
\end{tabular}


By multiplying the total destroyed area (9 600.59 ha) with the average increment of the affected area $\left(5.9 \mathrm{~m}^{3} / \mathrm{ha}\right)$ an overall increment of the destroyed area $\left(70113.77 \mathrm{~m}^{3}\right)$ was obtained. An overall increment was then multiplied with an average value of $41.32 € / \mathrm{m}^{3}$ and with 30 (the number of years in which we can expect a complete recovery of the affected areas) and it resulted with the loss of timber increment in the amount of $70205691 €$.

Finally, the total damage of timber is the sum of all three components (loss of values of damaged and destroyed forests, increased costs of harvesting, loss of timber increment) amounted to $163993205 €$.

\section{Damage on forest roads and forest skid-trails}

The total estimated damage on forest roads and forest skid-trails is summarized in Table 3.

FA Delnice is the most affected area by the overall damage caused by ice-break. Damages include forests and forest roads. A total of 2703 $\mathrm{km}$ of existing skid-trails need to be repaired. It was also estimated that it is necessary to build $23.18 \mathrm{~km}$ of new skid-trails in order to allow access and recovery of damaged and destroyed forest stands. In other affected areas (FA Zagreb, FA Sisak, FA Karlovac, FA Ogulin) damage on forest roads and forest skid-trails mostly occurred as a result of the impact of huge amount of water which damaged the roads or simply deposited materials onto them, and which should consequently be removed and the top layer of the road repaired.

Furthermore, the cost of undertaking of emergency measures for establishing public roads amounted to $61592 €$ and to $11846 €$ for FA Delnice and FA Ogulin, respectively.

\section{Cost of recovery (sowing and planting) for destroyed stands}

Total cost of recovery was calculated based on 9600 ha of identified priority areas and it amounted to $65449263 €$ (Table 4).

\section{Cost of damage (loss of value) of forest ecosystem services (FES)}

Calculation of costs of damage, i.e. calculation of the loss of value of FES is shown in Table 5. Average FES values in the management units affected by disaster are 22.5 points (HRK/ ha/year) and 19.5 points for state-owned and privately-owned forests, respectively. These values were reduced by $40 \%$ for highly damaged forest stands and by $20 \%$ for less damaged stands (Annex 1, Table FES-1) [14]. The calculated compensation values for each damage class (destroyed, highly damaged and less damaged forest stands) and ownership type (state owned and privately owned forest stands) were then multiplied with the corresponding forest area.

The total cost of losing forest ecosystem services (FES) amounted to $709619178 €$.

TABLE 3. Summarized costs of damages on forest roads and forest skid-trails

\begin{tabular}{|c|c|c|c|c|}
\hline \multirow{2}{*}{$\begin{array}{c}\text { Forest } \\
\text { Administration }\end{array}$} & \multicolumn{4}{|c|}{ Type of damage } \\
\hline & $\begin{array}{l}\text { Damages on } \\
\text { forest roads } \\
\qquad(€)\end{array}$ & $\begin{array}{l}\text { Damages on } \\
\text { forest skid-trails } \\
(€)\end{array}$ & $\begin{array}{l}\text { Construction of } \\
\text { new skid-trails } \\
(€)\end{array}$ & $\begin{array}{c}\text { Total } \\
(€)\end{array}$ \\
\hline Delnice & 445956 & 1199278 & 190060 & 1835294 \\
\hline Karlovac & 390415 & & & 390415 \\
\hline Sisak & 180399 & & & 180399 \\
\hline Zagreb & 695511 & & & 695511 \\
\hline Ogulin & 15480 & & & 15480 \\
\hline Total & 1727761 & 1199278 & 190060 & 3117099 \\
\hline
\end{tabular}


TABLE 4. Total cost of recovery for destroyed stands - identified priority areas encompass 9600 ha

\begin{tabular}{|c|c|c|c|c|c|}
\hline \multirow[t]{2}{*}{ Activity } & \multirow[t]{2}{*}{ Rate } & \multicolumn{2}{|c|}{$\begin{array}{c}\text { Employment } \\
(\%)\end{array}$} & \multirow[t]{2}{*}{ Quantity } & \multirow[t]{2}{*}{$\begin{array}{l}\text { Cost } \\
\left(€ \cdot \text { ha }^{-1}\right)\end{array}$} \\
\hline & & $\begin{array}{l}\text { Croatian } \\
\text { Forests }\end{array}$ & $\begin{array}{l}\text { External } \\
\text { Services }\end{array}$ & & \\
\hline Preparation of soil & $10 \mathrm{wd} / \mathrm{ha}$ & 30 & 70 & $\begin{array}{l}\text { Manual-machine } \\
\text { work }\end{array}$ & 585.00 \\
\hline Planting material & $8000 \mathrm{pc} / \mathrm{ha}$ & 100 & & $\begin{array}{l}\text { Broadleaved, } \\
2+0\end{array}$ & 2652.63 \\
\hline Planting material & $1000 \mathrm{pc} / \mathrm{ha}$ & 100 & & $\begin{array}{l}\text { Conifers, } \\
1+0\end{array}$ & 368.42 \\
\hline Planting of stock-seedlings & $49 \mathrm{wd} / \mathrm{ha}$ & 30 & 70 & 8000 pc (Beech) & 1977.11 \\
\hline Planting of stock-seedlings & $12.79 \mathrm{wd} / \mathrm{ha}$ & 30 & 70 & $\begin{array}{l}8000 \mathrm{pc} \\
\text { (Conifers) }\end{array}$ & 519.87 \\
\hline Transport of planting material & 1 machine & 30 & 70 & day & 177.90 \\
\hline $\begin{array}{l}\text { Total cost of planting of new } \\
\text { young stand }\end{array}$ & & & & & 5695.92 \\
\hline $\begin{array}{l}\text { Cost of tending and protection of } \\
\text { young stand }\end{array}$ & $\begin{array}{l}\text { 1) } 8 \mathrm{wd} / \mathrm{ha} \\
\text { 2) } 5 \mathrm{wd} / \mathrm{ha}\end{array}$ & 30 & 70 & ha & 523.42 \\
\hline $\begin{array}{l}\text { Cost of additional revision of } \\
\text { Forest Management Plan }\end{array}$ & & 100 & & & 13.29 \\
\hline Total cost $\left(€ \cdot \mathrm{ha}^{-1}\right)$ & & & & & 6817.63 \\
\hline Total cost $(€)$ & & & & & 65449263 \\
\hline
\end{tabular}

TABLE 5. Cost of damage of forest ecosystem services (FES)

\begin{tabular}{|c|c|c|c|c|c|}
\hline \multirow[t]{2}{*}{ Ownership } & \multirow{2}{*}{$\begin{array}{c}\text { Average FES } \\
\text { value } \\
\text { (points) }\end{array}$} & \multirow{2}{*}{$\begin{array}{c}\text { Compensation } \\
\text { (HRK) }\end{array}$} & \multirow{2}{*}{$\begin{array}{l}\text { Area } \\
\text { (ha) }\end{array}$} & \multicolumn{2}{|c|}{ Damage cost } \\
\hline & & & & (HRK) & $(€)$ \\
\hline \multicolumn{6}{|c|}{ Destroyed forest stands } \\
\hline State-owned & 22.5 & 255000 & 7377 & 1881135000 & 247517763 \\
\hline Privately-owned & 19.5 & 190000 & 2430 & 461700000 & 60750000 \\
\hline \multicolumn{6}{|c|}{ Highly damaged forest stands } \\
\hline State-owned & 9.0 & 55000 & 9522 & 523710000 & 68909211 \\
\hline Privately-owned & 7.8 & 51000 & 9723 & 495873000 & 65246447 \\
\hline \multicolumn{6}{|c|}{ Less damaged forest stands } \\
\hline State-owned & 4.5 & 36750 & 45821 & 1683921750 & 221568651 \\
\hline Privately-owned & 3.9 & 34000 & 10199 & 346766000 & 45627105 \\
\hline \multicolumn{4}{|c|}{ Total - State-owned } & 4088766750 & 537995625 \\
\hline \multicolumn{4}{|c|}{ Total - Privately-owned } & 1304339000 & 171623553 \\
\hline \multicolumn{4}{|c|}{ Total } & 5393105750 & 709619178 \\
\hline
\end{tabular}

Total damage of forests and forest infrastructure

Total damage to forest stands and forest infrastructure calculated by summarizing all estimated costs amounted to $942178745 €$.
If the costs of the undertaken emergency measures on public traffic (73 $438 €$ ) is added to the cost of total damage, the overall amount is then increased to $942252183 €$. 


\section{DISCUSSION AND CONCLUSIONS}

The methodology of rapid damage assessment presented in this paper resulted on the first, preliminary estimate of the range, intensity and cost of forest damage caused by recent natural disasters that occurred at the beginning of 2014 in five Croatian counties. The estimate of forest damage based on field observation, spatial data of forest management units and data from the existing Forest management plans was done in accordance with the existing regulations [9-14].

According to the conducted assessment, forests of FA Delnice (Primorsko-goranska County) are the most affected by the overall damage caused by ice-storm. Major damages occurred both on the forest and on forest roads. Ice-storm also caused serious damages of forests and forest roads of FA Senj (Ličkosenjska County) and FA Ogulin (Karlovačka County), while floods and torrents caused damages on forest roads in FA Zagreb (Zagreb County), FA Sisak (Sisačko-moslavačka County) and FA Karlovac (Karlovačka County).

In the total amount of damage expressed in money (942 $252183 €$ ), the loss of value of FES makes the biggest part (75\%). The loss of value of timber from damaged and destroyed stands and the cost of recovery of forest stands amounts to $17 \%$ and to $7 \%$ of the total estimated damage, respectively. Other costs in the amount less than $1 \%$ of the overall damage include costs of reconstruction of damaged forest roads and forest skid-trails, as well as, construction of new ones.

More precise data on forest damage will be known after the implementation of emergency recovery measures. Also, certain improvements of methodology used in this case in terms of precision and collection of data may be achieved by incorporating remote sensing methods.

\section{Incorporation of Remote Sensing Methods}

In case of a limited or completely restricted access to forest, remote sensing methods may have advantage over terrestrial methods. Remote sensing methods allow fast and reliable assessment of the affected area [19, 24-26] and give precise information on the range and intensity of the damage caused to forest or forest infrastructure.

Continuous technological development strongly affects the development of remote sensing methods and widens the area of application of these methods. Digital aerial photogrammetric cameras facilitate capturing of digital aerial images of very high spatial resolutions (usually with pixels size from 10$30 \mathrm{~cm}$ ) and the radiometric resolution [27-29]. Satellite images have an increasing application in forestry not only due to its spatial resolution (less than $50 \mathrm{~cm}$ ) but also due to lower costs when compared to aerial images. This is of special importance when large areas have to be taken into account [30]. Furthermore, the main features of satellite images are its spectral resolution (higher number of spectral channels compared to aerial images) and the high temporal resolution (frequency of taking images of the same area). Some satellites (e.g. WorldView 2) make a daily survey of a specific point on the Earth's surface. Aerial and satellite images enable quality visual interpretation on the tree scale taking into consideration their features. Remote sensing methods are hence a superior choice for the assessment of damage distribution, intensity and monitoring of success of recovery.

However, in this case, due to a very short period for the delivery of the report on damage assessment which was considerably shorter than the expected delivery time of satellite images (30-50 days), the initial assessment of the damaged area and intensity was conducted by using terrestrial methods. Also, most of the days after recent nature disasters had bad weather conditions (fog, low clouds), and consequently, using the remote sensing data (satellite images) was questionable. Nevertheless, remote sensing methodology for the assessment of damaged area and intensity in this case is still highly recommended. The delayed remote sensing survey (after the occurrence of natural 
disasters) in spring time when the vegetation starts to grow is even better since it is possible to determine physiological damage of trees and be more specific in the proposed measures for recovery (sanation). These remote sensing images may than serve as a basis for monitoring of the progress of recovery.

\section{Severity and Long-Term Consequences for Forestry}

In view of the positive effects of forests on climate, oxygen production, air purification, regulation of water table, prevention of erosion and landslides, population health, and the whole biosphere, the value of forests being reduced or completely nullified by large natural disasters is invaluable. Because of this, the seriousness and the longevity of effects on forest ecosystems, biodiversity and economy in this case, forestry has to be especially emphasized.

Overthrown trees and breakages of stem or branches and parts of crown, e.g. tree tops in conifers as the result of ice, in some areas have caused total blockage of roads and skid-trails, making large parts of forests inaccessible, and leaving a large number of forest roads damaged after the withdrawal of ice and water.

The damages in forests, be it individual trees or entire stands, in different degrees and coverage at the scale of management units, have one common denominator - the change in health status, structure, quality and value of stands requiring extraordinary measures and a whole new approach when it comes to either resolving urgent restorations, or future management with the goal of mitigation of long term after effects.

If the restoration, mitigation and regeneration measures are not taken immediately, is going to have serious and long reaching consequences, but even with all measures that have been, or will be taken in the next couple of months, the damage and after effects will continue to emerge through a longer time period. Generally, we can say that the regeneration of a forest stand lasts on average about 30 years, so we have to assess the negative impact of increment reduction and non-wood value of forests for that time span.
Along with the degradation of the overall status of forest stands, we have to expect a significant effect on the economy linked to this resource, as due to increased volume of wood on the market the prices will likely fall. Also, the wood coming to the market in the course of restoration will not achieve the expected price not only due to increased volume of wood on the market, but also due to the lesser quality of the wood itself. The choice of wood assortments will also be disturbed and those of lesser quality and price will prevail, taking a toll on the financial result of the company.

Due to the urgency of managing a large number of operations in a short time, the price of their accomplishment may rise, additionally lowering the income from wood. Additionally, in a longer timeframe, the costs of forest tending and regeneration will increase, and we should expect more tree dieback after a few years due to the increased activity of secondary pests and diseases and the changed ecological and stand conditions.

All this points due to the serioussness of the established situation, for which the costs of damage will be added for years to come, with regeneration, nursing and protection measures adding to the management costs. The newly developed situation puts in front of the forest practice and science a large challenge - how to, in the shortest time possible, restore the stability and grandeur of these forests, requiring the adaptation of forest management with new silvicultural and management methods for the future.

\section{Emergency Recovery Measures}

For the urgent recovery measures by logging and regeneration one quarter of destroyed forest stands were proposed according to the emergency assessment made by experts on the terrain.

The rest of damaged forest areas need to be recovered by using enhanced, and revised regular trees-marking, other measures of cutting, exploitation and cleaning of forest stands with smaller diameters, which have been damaged the most. 
Damaged stands, as in our example of beech stand, in order to protect the forest soils on the steep slopes and thin and skeletal soils, require rapid recovery due to the possibility of erosion on that torrential area where there is a high possibility of soil washouts due to large amounts of precipitation.

Tree-marking and measurement, as well as, record of all the damaged trees need to be done at the destroyed stands, and those trees having a chance to recover shall be left, and marked trees must be removed from the stand. Because of the steep and inaccessible terrain at these stands, the new forest roads and forest skidtrails that will enable removing all felled timber with at least damage to future young stands as possible have to be designed and constructed.

After the exploitation of the timber, an assessment of rejuvenation on forest compartment area has to done, or, in other words, the assessment of the seedlings, yearlings and saplings which can be counted on as a future stand. The other parts of damaged forests have to be planted by deciduous seedlings ( 8000 pcs (units)/ha) and conifers seedlings (1000 pcs (units)/ha), in other words (or,) taught by this kind of experience, to establish mixed forest stands that would have greater stability and have better possibility of survival given these and similar situations.

All emergency measures, as well as those that will come after them have been described in previous chapters and in rough form consist of, intensified work on measurement, tree-marking and exploitation, part-revisions of forest management plans as a results of significant changes in the stands which are looking for a change of management plans for the future management, more intensive activities on the reconstruction of damaged roads, especially forest roads and skid-trails and construction of the new required for the urgent recovery activities. Urgent recovery by using tree felling and the regeneration of damaged stands with the establishment of new ones with implementation of all the preparatory and protective (measures) as well as silvicultural measures during the establishment of young forest stand.

\section{Acknowledgments}

This study was produced with the major help of employees of Croatian forests Ltd. Authors would like to thanks employees of Forest Administration Delnice for collection of field data and maps production, as well as to employees of the Sector for Planning, Analysis and IT (Danko Kuric, Željko Tomašić, Domagoj Troha) for the great help in organizing the whole work.

\section{Supplementary materials}

Supplementary material 1. Map of broadleaved forests damaged by ice-break (http://www. seefor.eu/supp_material/vuletic_et_al_1.pdf) Supplementary material 2. Map of coniferous forests damaged by ice-break (http://www. seefor.eu/supp_material/vuletic_et_al_2.pdf) Supplementary material 3. Map of broadleaved forests destroyed by ice-break (http://www. seefor.eu/supp_material/vuletic_et_al_3.pdf) Supplementary material 4. Map of coniferous forests destroyed by ice-break (http://www. seefor.eu/supp_material/vuletic_et_al_4.pdf)

\section{REFERENCES}

1. SCHELHASS M-J 2008 Impacts of natural disturbances on the development of European forest resources: application of model approaches from tree and stand levels to large-scale scenarios. Alterra Scientific Contributions 23: 168 p. URL: http://edepot.wur.nl/146827 (10 March 2014)
2. KING D J, OLTHOF I, PELLIKKA K E, SEED E D, BUTSON C 2005 Modelling and mapping damage to forests from an ice storm using remote sensing and environmental data. Nat Hazards 35 (3): 321 342. DOI: http://dx.doi.org/10.1007/s11069-0041795-4 
3. SHI L, WANG H, ZHANG W, SHAO Q, YANG F, MA Z, WANG Y 2013 Spatial response patterns of subtropical forests to a heavy ice storm: a case study in Poyang Lake Basin, southern China. Natural Hazards 69 (3): 2179-2196. DOI: http:// dx.doi.org/10.1007/s11069-013-0800-1

4. ASZALÓS R, SOMODI I, KENDERES K, RUFF J, CZÚCZ B, STANDOVÁR T 2012 Accurate prediction of ice disturbance in European deciduous forests with generalized linear models: a comparison of field-based and airborne-based approaches. European Journal of Forest Research 131 (6): 1905-1916. DOI: http://dx.doi.org/10.1007/ $\underline{\text { s10342-012-0641-6 }}$

5. SCHELHAAS M J, NABUURS G J, SCHUCK A 2003 Natural disturbances in the European forests in the 19th and 20th centuries. Global Change Biology 9 (11): 1620-1633. DOI: http://dx.doi. org/10.1046/j.1365-2486.2003.00684.x

6. DRAGIŠIĆ $P$, HREN V 1963 Reconstruction of forsts areas in Management unit "Čorkovačka-Karlice" destroyed by ice brackege with fast growing conifers (in Croatian). Study, Institute for forestry and hunting, Zagreb, Croatia

7. PRPIĆ B 1966 Damage caused by ice coating on tree crowns in the management unit "Josip Kozarac", forest District of Lipovljani (in Croatian). Sumar List 90 (7-8): 347-360.

8. HREN V, CESTAR D, KREJČI V, ŠUBARIĆ । 1983 Recovery of forest damaged by ice-break in Lika (in Croatian). Forest Research Institute, Jastrebarsko, Croatia, $21 \mathrm{p}$

9. CROATIAN PARLIAMENT 1998 The Methodology for Damage Assessment Caused by Natural Disasters (in Croatian). Official Gazette 96/98, Zagreb, Croatia. URL: http://narodne-novine. nn.hr/default.aspx (12 February 2014)

10. CROATIAN PARLIAMENT 19897 Law on Protection from Natural Disasters (in Croatian). Official Gazette 73/97, Zagreb, Croatia. URL: http:// narodne-novine.nn.hr/default.aspx (12 February 2014)

11. CROATIAN PARLIAMENT 2013 Law on forests (in Croatian). Official Gazette 140/05, 82/06, 129/08, 80/10, 124/10, 25/12, 68/12, 148/13. URL: http:// narodne-novine.nn.hr/default.aspx (12 February 2014)
12. MINISTRY OF AGRICULTURE AND FORESTRY 1997 Regulations on forest management - Chapter VIII, Determination of fees for transferred and limited rights to forest and forest land (in Croatian). Official Gazette 11/97, 121/97, Zagreb, Croatia. URL: http://narodne-novine.nn.hr/default.aspx (12 February 2014)

13. MINISTRY OF AGRICULTURE, FORESTRY AND WATER MANAGEMENT 2007 Regulations on the method of accounting, forms and deadlines for payment of fees for the forests ecosystem services (FES) (in Croatian). Official Gazette 22/07, Zagreb, Croatia. URL: http://narodne-novine.nn.hr/default. aspx (30 March 2014)

14. MINISTRY OF REGIONAL DEVELOPMENT, FORESTRY AND AND WATER MANAGEMENT 2011 Regulation on the fee transferred and limited rights on forest and forest land (in Croatian). Official Gazette 105/09, 098/11, Zagreb, Croatia. URL: http:// narodne-novine.nn.hr/default.aspx (30 March 2014)

15. MILLER-WEEKS M, EDGAR C 1999 Ice Storm 1998 - A Forest Damage Assessment for New York, Vermont, New Hampshire and Maine. North East State Foresters Association and USDA Forest Service, State and Private Forestry, USA, $34 \mathrm{p}$. URL: $\quad$ http://na.fs.fed.us/fhp/ice/durham/pubs/ ice storms/ice98 damage assessment.pdf (10 February 2014)

16. VULETIĆ D 2001 Effect of Mechanical Damage to Trees on Assortment Quality of Pedunculed Oak (Quercus robur L.) (in Croatian with English summary). Rad -Šumar inst Jastrebar 36 (1): 15-32

17. WALKINGSTICK T 2002 Evaluating ice damage to forest stands. University of Arkansas, Division of Agriculture, Cooperative Extension Service, Little Rock, AR, USA, $2 \mathrm{p}$

18. VULETIĆ D, SABADI R, PALADINIĆ E 2004 First Assessment of the Total Economic Value of Croatian Forests (in Croatian with English summary). Rad -Šumar inst Jastrebar 39 (1): 79-98

19. MILLWARD A A, KRAFT C E, WARREN DR 2010 Ice Storm Damage Greater Along the TerrestrialAquatic Interface in Forested Landscapes. Ecosystems 13 (2): 249-260. DOI: http://dx.doi. org/10.1007/s10021-010-9314-9

20. CROATIAN FOREST LTD 2006 General Forest Management Plan of the Republic of Croatia (2006-2015). Approved by the Ministry of Agriculture, Forestry and Water Management, $566 \mathrm{p}$ 
21. VULETIĆ D, POSAVEC S, KRAJTER S, PALADINIĆ E 2010 Payments for environmental services (PES) in Croatia - public and professional perception and needs for adaptation. South-East Eur For 1 (2): 6166. DOI: http://dx.doi.org/10.15177/seefor.10-07

22. DELIĆ S, BEĆIROVIĆ DŽ 2012 The importance and necessity of total economic valuation of forests. In: Scientific conference "Forests as quality indicators of environment". Academy of Science of Bosnia and Herzegovina

23. DELIĆ $S$, VULETIĆ $D$, ZADNIK-STIRN L, AVDIBEGOVIĆ M, BEĆIROVIĆ DŽ, MUTABDŽIJA S, MARIĆ B, PEZDEVŠEK-MALOVRH Š 2013 Models of Financing Forest Ecosystem Services in the Federation of Bosnia and Herzegovina, Croatia and Slovenia. In: Šišák D, Dudík R, Hrib M (eds) Socio-economic Analyses of Sustainable Forest Management, Prague, Czech Republic, 15-17 May 2013. IUFRO Unit 4.05.00 (Managerial economics and accounting) and Czech University of Life Sciences Prague, Prague, Czech Republic, pp 1522.

24. OLTHOF I, KING D J, LAUTENSCHLAGER R A 2004 Mapping deciduous forest ice storm damage using Landsat and environmental data. Remote Sens Environ 89 (4): 484-496. DOI: http://dx.doi. org/10.1016/j.rse.2003.11.010

25. ASZALÓS R, SOMODI I, KENDERES K, RUFF J, CZÚCZ B, STANDOVÁR T 2012 Accurate prediction of ice disturbance in European deciduous forests with generalized linear models: a comparison of field-based and airborne-based approaches. European Journal of Forest Research 131 (6): 1905-1916. DOI: http://dx.doi.org/10.1007/ $\underline{\text { s10342-012-0641-6 }}$
26. SUN Y, DICKINSON R E, ZHOU B 2012 Forest greenness after the massive 2008 Chinese ice storm: integrated effects of natural processes and human intervention. Environ Res Lett 7 (3): 7p. DOI: http://dx.doi.org/10.1088/17489326/7/3/035702

27. SANDAU R 2010 Digital airborne camera, introduction and technology. Springer, Dordrecht, Netherlands, 343 p. DOI: http://dx.doi. org/10.1007/978-1-4020-8878-0

28. BALENOVIĆ I, SELETKOVIĆ A, PERNAR R, MARJANOVIĆ H, VULETIĆ D, PALADINIĆ E, KOLIĆ J, BENKO M 2011 Digital Photogrammetry State of the Art and Potential for Application in Forest Management in Croatia. South-east Eur For 2 (2): 81-93. DOI: http://dx.doi.org/10.15177/ seefor.11-09

29. BALENOVIĆ I, MARJANOVIĆ H, INDIR K, VULETIĆ D, OSTROGOVIĆ M Z, BENKO M 2013 Estimation of the Stands' Arithmetic Mean Diameter using Manual Method of Digital Photogrammetry. Period Biol 115 (3): 399-407

30. SELETKOVIĆ A, PERNAR R, ANČIĆ M, SUČIĆ J 2011 Assessment of stand structural elements on the basis of spectral reflectance values of an IKONOS satellite image. Croat J For Eng 32 (1): 329-343 
